\title{
Economic status and use of complimentary energy sources to electricity among households within Nakuru municipality
}

\author{
Maina J. Kairu, Oyugi Tobias \\ Department of Education and External studies, University of Nairobi, Nairobi, Kenya \\ Email address: \\ mainakairu@yahoo.com (J. K. Maina),koyugibft@gmail.com (T. Oyugi)
}

\section{To cite this article:}

Maina J. Kairu, Oyugi Tobias. Economic Status and Use of Complimentary Energy Sources to Electricity among Households within Nakuru Municipality. International Journal of Economics, Finance and Management Sciences. Vol. 3, No. 1, 2014, pp. 16-26. doi: 10.11648/j.ijefm.20150301.13

\begin{abstract}
This study sought to investigate the relationship between economic status and use of complimentary energy sources to electricity among households within Nakuru Municipality. The study was premised on the desire of Kenya to be a middle income economy by the year 2030, in which case a substantial capacity of electrical energy will be required to power the anticipated industrial activity hence the need to conserve electrical energy which would in turn be utilized in the manufacturing sectors. Households are considered to play a role in inefficient usage of electricity. Literature reviewed has revealed that in rural areas of Kenya $52 \%$ use kerosene for lighting and $60 \%$ for cooking, this study however has found out that electricity is dominantly used for lighting within households of the Municipal Council of Nakuru (MCN), the households prefer solar energy as an alternative to electricity. However affordability is a challenge owing to the prohibitive capital cost compounded by house ownership issue. This study adopted correlational survey design and relied on both qualitative and quantitative data. Descriptive and Chi-Square Tests were used in data analysis to establish the relationship between the two variables. The population of the study was the entire houses owned by the MCN which in total add up to 5434 houses. A representative random sample size of 358 households was used in the study. Data was collected using Questionnaires and key informants interviews. The study found out that electricity was commonly used for lighting and normal domestic use. The study revealed a positive relationship between economic status of households and usage of complimentary energy sources to electricity among the households. The researcher recommended a further study on the evaluation of electricity usage among owner occupied residential houses that have a greater flexibility of choosing the kind of electrical installation as opposed to tenants.
\end{abstract}

Keywords: Income Level, Complimentary Energy Sources, Nakuru Municipality

\section{Introduction}

Municipal Councils all over the world are responsible for construction and provision of housing to its residents, the Local Government Act Cap 265 mandates municipalities to develop and maintain houses as a social responsibility. The councils may partner with other development agencies in undertaking this noble function. A case of Kenya is where the National Housing Cooperation develops housing estates which are managed by the Municipal Councils. Once the buildings had been allocated to tenants it is of interest to find out what challenges exist especially on the use of electricity and also bearing in mind that Electricity is the most commonly used form of energy in many households in the world. (World Bank, 2006)

The Kenya Vision 2030 envisages Kenya to be a middle income economy by the year 2030 (GOK, Kenya Vision 2030). To achieve this, the country requires a substantial energy based to be able to power increased industrial activity (Muma et al, 2014). To that end therefore more energy should be conserved for the industrial purpose. However, the biggest proportion currently of electricity consumption goes into domestic use by households (GOK, Kenya Vision 2030). As Kenya aspires to be a middle income economy as envisaged in its Vision 2030, it faces an enormous task of meeting energy needs due to the high expectations in growth to power the economy. Kenya Power and Lighting Company (KPLC) has more than 550,000 customers who consume an average of 3.6 billion kilowatt hours of electricity every year (ERC, 2010). For the past 
five years, growth in electricity had been affected by the severe drought experienced in 1990's to 2008 and the decline in economic growth. This maximum demand was to be $850 \mathrm{MW}$ by mid-2005 and this trend has been increasing. In the long term, the installed capacity was projected to increase by 1342 MW between 2004 and 2018/2019 and will comprise of geothermal (503 MW), hydro (220.6 MW) and thermal (568.7 MW) sources. National consumption of electricity was projected to rise from 4.9 billion kilowatt hours in $2003 / 2004$ to 5.1 billion in $2004 / 2005$, and 6.9 billion kilowatt hours in $2009 / 2010$ and to 11.8 billion in 2010/2011 (ERC, 2010).

Alternative to electricity energy were found to be equally unsustainable or were not embraced by the majority of the population. Unsustainable increased use of biomass energy causes deforestation and land degradation. Since energy is crucial to achieving sustainable development goals, the challenge laid on finding ways to reconcile this necessity and demand for energy with its impact on the natural resource base (Muma et al., 2014). The conservation mechanisms are therefore very important and analysis of consumption trends of any form of energy is therefore very important.

Given the central role of energy in the economy and also its potential for poverty reduction and wealth creation, it is critical to assess how Kenya can secure energy supply in the future in order to achieve Vision 2030. Currently, there are serious constraints in energy supply in Kenya, which include low access to modern energy services, high cost of energy, irregular supply and high cost of energy investments. The ambitious Vision 2030 targets will exacerbate this problem. There is a huge unmet demand for electricity in Kenya. In 2000, the unmet demand for electricity was approximately 25 per cent (KIPPRA, 2010). The biomass energy deficit was estimated at 60 per cent in 2004. Access to forms of modern energy is very low (KIPPRA, 2010). The per capita consumption of electricity in Kenya is very low at $121 \mathrm{kWh}$ compared, for example with 12,235 kWh for US, $6172 \mathrm{kwh}$ for South Korea, $1970 \mathrm{kwh}$ for Brazil, $769 \mathrm{kwh}$ for China and $411 \mathrm{kwh}$ for India (KIPPRA,2010). The national access rate for electricity of about 15 per cent is below the average of 32 per cent for developing countries (KIPPRA, 2010).

\subsection{Objective of the study}

1. To assess the household economic status and price levels within Nakuru Municipality

2. To assess the level of alternative energy use among households within Nakuru Municipality

3. To determine the relationship between level of income and usage of alternative energy sources to electricity among households within Nakuru Municipality

\subsection{Study Hypothesis}

The study tested the following hypothesis;

Ho: There is no significant relationship between Energy economic status and usage of complimentary/alternative energy sources to electricity.

\subsection{Significance of the Study}

The study is expected to inform Municipal council of Nakuru Housing department of relevant infrastructural development for efficient power conservation in their future projects. Independent Power Producers, and all parastatals under the Ministry of Energy like KPLC, KENGEN, KREP, ERC among others are expected to benefit from the findings of this study. The study findings are hoped to provide a better understanding of modern households' electricity use patterns and how income level influence energy use. The findings the research will contribute to a better understanding of the present problems and provide solutions to the effective use of electric energy.

\subsection{Conceptual Framework}

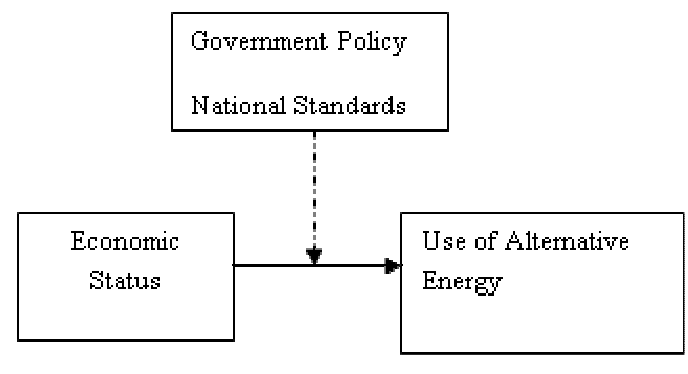

Figure 1. Conceptual Framework

\section{Literature Review}

\subsection{Household Economic Status and Energy Prices}

One of the important determinants of household energy demand and fuel mix is the price of various fuels. It is often difficult to estimate the effect of price in developing countries where a major part of energy consumption is met by traditional fuels that are gathered informally with no cash outlays. Noncash costs consist mostly of time (e.g., for gathering wood fuel) and hence are opportunity costs. Commercial energy prices are often used as a social policy instrument in developing countries (Longo \& Petrucci, 2008).

Among the most common subsidized energy sources for households is electricity, with the aim of making it accessible even to low income households. However, in many cases such programs have resulted in effectively subsidizing higher income people who live in urban areas and have access to electricity grids. For the rural and urban poor, connection to the electricity supply is often prohibitively expensive or unavailable, even though the price of electricity itself may be low enough to encourage a switch from other fuels.(Longo \& Petrucci,2008) In general, policies that keep energy prices low have led to growth in latent or potential household energy demand. Effective demand may not increase to the same extent if capacity constraints preclude an expansion of supply.

Recent efforts to restructure electricity markets have renewed interest in electricity demand and its relation to prices. This interest reflects a growing appreciation for the role of demand in competitive power markets generally, and the 
specific concern that retail electricity prices were now changing - for some consumers, quite substantially. (Roe \& Russel, 2001)

Because electricity is nearly universally sold using (nonlinear) tariffs and consumers are a heterogeneous lot, the impact of these price changes can vary widely from one household to another. This, in turn, affects the design of price schedules and other price-based subsidy programs common to energy policy debates. In as much as tariff designs would continue to be revised as this industry evolves, it becomes desirable to understand how they affect consumers' behavior (Jadreesic, 2000)

To appreciate why practitioners often possess an incomplete understanding of how consumers would respond to a new tariff design, consider the problems involved. Difficulties that researchers typically face in modeling electricity demand included the nonlinearities of tariff schedules, aggregation of consumption behavior over time and appliances, and the interdependence of energy use with longer-term household decisions over appliance ownership and dwelling characteristics (Otivar, 2009).

The first two issues in tandem pose complex simultaneity problems between marginal prices and observed consumption outcomes. These must be disentangled to recover a household's demand elasticity. The third issue imposes high data requirements (information on household-specific appliance holdings and residence features), and creates heterogeneity in consumption responses related to the characteristics of these durable goods. When the researcher's objective was to develop a model for simulating the effects of prospective tariff changes, ignoring such features will provide an incomplete assessment of demand responses and potentially misleading predictions of a new design's consumption and revenue consequences. (Rabah, 2005)

Some of the energy consuming activities within a typical household are lighting, cooking, refrigeration, water heating, laundry, ironing, and air conditioning. The common home also has entertainment equipment such as radio, TV, DVD, and VCR. These appliances and activities improve our lifestyle. In order to get maximum benefits from electricity, we should use these appliances and carry out these activities safely and efficiently. Energy consumed by households includes electricity, gas, diesel, kerosene, inverters, candles, lanterns etc. (Wamukoya, 2007). However, consumption is dominated by electricity and this paper is to look at energy efficiency in the homes in relation to house lighting habits and use of appliances.

According to ABS data (2010) cited in Bord (2011), despite efforts to reduce energy consumption in homes, household electricity use per person had been on the increase. Larger dwelling size, decreasing average household size, more appliances and IT equipment per households as well as the increased use of heaters and coolers, have contributed to the increase. Efforts to improve energy efficiency by government can be frustrated by complexity of human behavior including “take back" Howden- chapman et al (2009).

The enormity of Nigeria's energy problem creates a greater need for energy efficiency practice to be adopted by residential households as electricity demand in Nigeria far outstrips the supply which was epileptic in nature (Sule, Habeeb, Ajimotokan and Garba 2011). Energy efficiency had become the key driver for sustainable development. If we use energy more efficiently it will lead to saving of personal income and reduce the need for more power stations in the country (Otegbulu 2011, CREDC 2009). In the last few years more stringent environmental laws and souring energy prices had increased the need for household to react and participate in energy reduction and housing sustainability (Eves and Kippes 2010). The potential for efficient energy utilization and conservation amongst residential households as it accounts for approximately one third of overall delivered energy use and carbon dioxide emissions (Business Enterprise and Regulatory Reform 2008, Sambo 2005). In the past 20 years, there have been a growing awareness and focus on energy efficiency in residential house design, construction materials and equipment heating and cooling. Much of this work commenced in the USA in the mid 1980's with the introduction of Home Energy Rating Schemes (HERS) and demand side management programs, as well as rating for construction and energy use in property (Ding 2008) cited in (Eves and Kippes 2010).

\subsection{Sources of Energy}

In Kenya, electricity is mainly generated from hydro, thermal and geothermal sources. Wind generation accounts for less than six megawatts of the installed capacity. Currently, hydro power comprises over 60 percent of the installed capacity in Kenya and is sourced from various stations managed by the Kenya Electricity Generating Company (Ken Gen, 2004).

Hydro power is generated by a process whereby mechanical energy produced by falling water is transformed into electrical energy. Thermal electricity is produced by the burning of fuel (fossil, nuclear, biomass etc.) to produce steam or gas which turns turbines that produce electricity. Geothermal electricity is generated from underground steam that is used to drive a conventional turbine to generate electricity (CAN, 2004).

Kenya Power is responsible for ensuring that there is adequate line capacity to maintain supply and quality of electricity across the country. The interconnected network of transmission and distribution lines covers about 41,486 kilometers. The national grid is operated as an integral network linked by a $220 \mathrm{kV}$ and $132 \mathrm{kV}$ transmission network. There is a limited length of $66 \mathrm{kV}$ transmission lines. The national grid impacts on the future growth of the energy sector because any new generation capacity must take into consideration the existing network and its capacity to handle new loads. Kenya Power reinforces the power transmission and distribution network by constructing additional lines and substations (Republic of Kenya, 2001).

Domestic energy consumption represents one area where the links between global environmental problems and individual behaviour are clearly identifiable, even if consumers do not immediately recognize the connection. This 
means that energy conservation has become one of the first sustainability issues to be addressed through a combination of national and local government policies (Nandi \& Bose, 2010). However, the promoters of energy conservation face a major problem: how to increase the visibility of domestic fuel consumption in homes and increase peoples' awareness of the links between their behaviour and problems such as global warming. To most consumers in developed countries, the fuel used within homes has become, to a large extent, an invisible resource, yet in the U.K. it accounts for 30 per cent of the energy produced. The only commonly visible record of consumption comes in the form of quarterly bills or monthly statements, by which time the links between specific activities and the energy consumed are severely dislocated, a situation described elsewhere as akin to a supermarket not displaying any individual product prices but merely providing the shopper with a total non- itemized bill at the checkout (Goett \& Hudson, 2000)

According to Longo and Petrucci, (2008)It was thus important to evaluate the way households consume power perhaps as a form of feedback for planning on effective use of energy. A repeated question had been whether feedback containing an element of comparison, either in terms of comparing one household to another or by comparing the same person's consumption with their previous consumption can work especially when comparing the various demographic characteristics of the households. .(Longo\&Petrucci,2008)

Another common theme that had concerned the issue of energy consumption was the personal values in the way electricity was used in the households; specifically whether household characteristics, economic motives or environmental motives influence behaviour and therefore whether feedback appealing to one or other of these values would be more successful in analysing the way electricity was used by households (Karekezi \& Kithyoma,2005).There had also been considerable exploration of the influence of a household's social-economic circumstances upon their energy consumption and take up of energy efficiency measures. However, rarely, if ever, had these various factors like household factors, adherence to standards, alternatives to electricity as a source of energy been considered together.

The work of Stern, (2000) has attested that self-monitoring works, and comparing one household with an area average is effective. Comparative feedback was also found to be very effective by Goet \& Hudson (2000) who examined how people changed their consumption if given the opportunity to compare their present consumption with a previous similar period. Other research has looked at whether feedback which emphasizes the financial costs of energy consumption, but more frequently than the typical quarterly bill has any impact (Balla, 2005).

Cooks \& Berenberg (1981), concluded that cost based energy feedback consistently resulted in reductions, and that people liked to receive breakdowns of their consumption in this way. Although Roe et al (1986) found out that feedback emphasizing financial values did not have positive results on conservation of electricity. A similar lack of agreement about the positive impact of feedback has arisen from research on the role of environmental attitudes and energy conservation; many commentators have suggested that the link between pro-environmental attitudes and concern about energy-related environmental issues and conservation behaviour is a weak one. (Roe et al., 1986)

However, Seligman and Kriss (1979) in their study found that 50 per cent of variance in energy use could be explained by attitudes towards energy conservation. People's perceptions of their own contribution to energy problems are predictive of household energy conservation and that information designed to promote energy consciousness should emphasize such values.

In terms of socio-demographic factors, Kasulis et al. (1981) have argued that if a household is on a low income, they are already very likely to be using low amounts of energy and thus would not have the ability to respond to requests for greater conservation activity. Similarly, people living in rented accommodation. Home ownership as a crucial factor, makes it possible to gain the personal benefits of investment, either in comfort, energy savings, property values, or whatever; renters are not likely to invest their money to improve the energy efficiency of their landlord's property (Otegbulu \& Austin, 2010). In this case it would be important to consider the effect of tenancy to Municipal council would have on electricity consumption in Nakuru Municipal Council. Despite the general consensus on the importance of energy consumption feedback reached by earlier research, the evaluation of the different social strata's in terms of household characteristics still remaining unclear.

Previous work has also been marked by a lack of research within a Kenyan context, and typically has involved rural households of a very short duration with small samples according to (Wamukonya, 2007). In addition, while it was largely agreed that favorable and unfavorable predispositions, structural, situational, and income and demographic variables were all likely to have an influence on changes in energy and specifically electricity conservation, they had been inadequately studied in urban settings. The proposed study therefore seeks to narrow the gaps in the literature and aims at documenting the conservation practices of electricity within Nakuru Municipal council houses which can as well be generalized to other urban centres in Kenya.

\subsection{Trends in Household Electricity Consumption}

The difference in per capita electricity consumption between developed and developing countries were greater than the difference for total energy. However, the growth in electricity consumption in most developing countries since 1971 had been faster than that of other fuels. Per capita household electricity use has grown faster than per capita income (Basa et al, 2009). Key factors in the growth of household electricity consumption are the number of households with access to electricity supply, penetration rates of electric appliances, and the size and efficiency of appliances. Access to electricity varies widely among and within developing countries, depending largely on per capita 
incomes and urbanization. Rapid growth in electrification rates in many countries reflects the impact of urbanization and of rural electrification programs (Goett \&Hudson, 2000)

The expected further growth in electricity consumption would have important consequences for power generation systems in developing countries. In some countries, household demand has accounted for a larger share of growth of electricity demand than industry, and in all cases the household sector represents a substantial proportion of the total increase in electricity demand (Howden \&Chapman, 2009)

A particular problem for power systems is that household electricity demand usually adds to peak loads. Growth in electricity demand therefore requires expansion of power generation capacity, for which there are insufficient financial resources in many developing countries under current energy sector policy regimes due to inadequate provision for cost recovery from users.

Urban electrification levels in the country are still very low. Only $47.5 \%$ of the entire urban population (nearly the entire medium and high income population) has access to electricity (World Bank, 2006). The limited available evidence indicates that the situation is worse in low-income urban households and in most peri urban areas. This is particularly troubling since the low-income areas are usually not very far from major electricity transmission and switching stations. Low-income areas are often close to the city center and are densely populated, thus the associated transmission and distribution costs of electricity extension are not high (Balla, 2006). In many cases, the costs are lower than the cost of extending electricity to low-density high-income areas

According to Ritchie et al. (1981,) the key determinants of energy demand in the household sector include: Prices of fuels and appliances:-Disposable income of households; Availability of fuels and appliances; Particular requirements related to each; and Cultural preferences. With increasing disposable income and changes in lifestyles, households tend to move from the cheapest and least convenient fuels (biomass) to more convenient and normally more expensive ones(charcoal, kerosene) and eventually to the most convenient and usually most expensive types of energy (LPG, natural gas, electricity).

There is also a correlation between the choice of cooking fuels and the value of women's time. Women who enter the formal workforce demand more convenience in their use of household fuels (Vandeplas \& Hawkins, 1998). For example, in Bangkok, that leads to a preference for LPG compared to more traditional fuels. There is a strong positive relationship between growth in per capita income and growth in household demand for commercial fuels. For most developing countries, demands for commercial fuels have risen more rapidly than per capita incomes since 1970. This reflects the increasing desire for comfort and discretionary energy consumption (Lea\&Tarpy, 1987) Urbanization Is an important determinant of both the quantity and the type of fuel used in developing countries. In general, urbanization has led to higher levels of household energy consumption, although it is difficult to separate the effects of urbanization from the increases in income levels that generally accompany urbanization. There is also a shift from traditional to commercial fuels. Several factors that have contributed to this trend include a decline in access to biomass fuels, inconvenience of transportation and storage, and improvement in availability of commercial fuels in urban areas (Roe \& Russsel, 2001)

Nonetheless, use of traditional fuels in many cities of the developing world remains high among low income groups. Another trend is a decline in the share of energy used for basic requirements such as cooking and lighting as incomes increase, while energy consumption for space heating, water heating, refrigeration, appliances, air conditioning and other modern uses grows (Otivar, 2009)

The difference in per capita electricity consumption between developed and a developing country is greater than the difference for total energy. However, the growth in electricity consumption in most developing countries since 1971 had been faster than that of other fuels. Per capita household electricity use had grown faster than per capita income. Key factors in the growth of household electricity consumption were the number of households with access to electricity supply, penetration rates of electric appliances, and the size and efficiency of appliances (Rabah, 2005). Access to electricity varies widely among and within developing countries, depending largely on per capita incomes and urbanization. Rapid growth in electrification rates in many countries reflects the impact of urbanization and of rural electrification programs. A particular problem for power systems is that household electricity demand usually adds to peak loads. Growth in electricity demand therefore require expansion of power generation capacity, for which there are insufficient financial resources in many developing countries under current energy sector policy regimes due to inadequate provision for cost recovery from users. (Ritchie et al 1981) compliments to electricity energy

In Kenya, energy resources comprised commercial and non-commercial. Commercial energy mainly comprise of petroleum products and electricity, while non-commercial comprise of biomass, and to a lesser extent solar energy, wind power and biogas. From the National Energy Matrix, total final energy consumption in Kenya in 2009 was $14,353.8$ thousand tonnes of oil equivalent while the total primary energy supply was 18,215.99. Petroleum fuel accounts for about $28.57 \%$ of the total final energy consumption while electricity and combustible renewable accounts for about $3.11 \%$ and $67.65 \%$ of the total final energy consumption. The energy sector contributes about $9.49 \%$ to GDP with the petroleum sector, electricity and fuel wood sector contributing $8.4 \%, 0.6 \%$ and $0.4 \%$ respectively.(MOE,2009).The GDP per unit of oil equivalent is PPP US\$ 2.98 compared to that of Botswana of US\$ 12 and Tanzania US\$ 2.53.

The use of LPG at homes, educational and health institutions has risen from slightly over 40 thousand metric tons in 2003 to 80 thousand metric tons in 2008 (KIPPRA, 2010). Motor gasoline which is mostly used in the transport of passengers and goods may not have made any remarkable 
growth owing to the efficiency of the vehicles entering the domestic market, in spite of the rise in numbers.

Automotive gas oil, the dual purpose fuel consumed by transport and agriculture, has a six fold rise between 2003 and 2008. Other products which recorded increased consumption include lubricating oils, as proof of the growth of transport vehicles and machinery for use in agriculture and manufacturing industries. Illuminating kerosene the most popular fuel for use by households in lighting and cooking used about 300 thousand cubic metres in 2008 as compared to about 200 thousand cubic metres consumed in 2003(KIPPRA,2010).

The analysis showed that about $70 \%$ of the consumers use biomass while $30 \%$ use other fuels. This supports well known studies that biomass provides $70 \%$ of the energy requirements (Kituyi, Kamfor 2002). The study showed kerosene to be mostly used for lighting (52\%) while biomass was widely used for cooking $(60 \%)$. The survey data showed that users of charcoal and fuel wood in Nairobi had to travel on average 0.59 and 6.44 kilometers respectively to access the fuel they need. With an exception of the transport fuels, average monthly consumption per household is high for electricity (386.01 Mega Joules) compared to the other fuels. The energy budget shares for households differ across the provinces, fuels as well as location, either rural or urban. Fuel wood has the highest energy budget share on average for both rural (11.6\%) and urban $(9.34 \%)$ compared to the other fuels (Kituyi \& Kamfor, 2002)

The ultimate source of energy for living organisms is the Sun of course. It supplies incredible amount of energy to the earth's surface (Southwick 1976). The total amount of solar energy striking the earth's surface each day is equivalent to the energy in 684 billion tons of coal $(6.84 \times 10 \times 11)$ tons. This is sufficient energy to produce light energy equivalent to that supplied by over 1,000,000 watts for each acre of ground. The solar energy striking the surface of the United States every 20 minutes is sufficient to meet the country's entire power needs for one year, if it could be harnessed (Southwick 1976). The study would endeavor to investigate why then is solar energy not popular yet it seemed to be the most cost effective, efficient and environmental friendly.

\section{Research Methodology}

\subsection{Research Design}

This study adopted both descriptive and correlational study research designs. According to Yin (2003) descriptive studies are used to describe an event/ process in its natural setting and the main objective is to answer how, who and what questions. The design is therefore suitable for this study as it seeks to evaluate factors influencing efficient use of electricity among households within Municipal Council of Nakuru. The research was also a cross sectional one as it seeks to study a particular phenomenon (or phenomena) at a particular time. The choice of this design was based on time and resource constraints. Descriptive studies are used to investigate contemporary phenomena; they do not require control over the investigated behavioral element but seeks interpretations of those people most knowledgeable in a subject matter.

\subsection{Target Population}

According to Municipal Council of Nakuru, Housing is the largest user of space in Nakuru Municipality. From a provider perspective there were two categories of housing; public and private. The former comprises of housing stock by the government, its corporations and municipal authorities for staff accommodation and council rental housing. The latter comprises of housing stock developed by individuals for rental purposes or for their own habitation. There are at least 6,956 public housing units within the town, 5434 of which were owned by the municipal council of Nakuru and 1,522 by the central government departments and corporations (MCN/BADC/UNCHS, 1999). Table 1 shows the population distribution.

Table 1. Distribution of the Nakuru Municipal Council Households

\begin{tabular}{ll}
\hline House Category & Number of Households \\
\hline Three Bedrooms & 15 \\
Two Bedrooms & 110 \\
One bedroom & 32 \\
Single Room/Bedsitter & 3522 \\
Total Population & 5,434 \\
\hline
\end{tabular}

Source: MCN, (2012)

\subsection{Sample Size and Sampling Procedure}

Cooper and Schindler (2000) defined a sampling frame as the list of elements from which the sample was drawn. The population of this study would comprise the three categories of residential houses of the Nakuru Municipal Council. The sampling frame was obtained from the Nakuru Municipal Council Rent and Housing Department and the Kenya National Bureau of Statistics Rift Valley Provincial headquarters. Multi- stage cluster sampling was used. The common multi stage cluster sampling is done when an entire population being studied involves area sampling as the first step. If areas are sampled, then everyone has an opportunity to fall into the sample, the researcher first drew a sample of designated areas, perhaps city estate houses or rural locations (Orodho, 2005). Stratified and random sampling was also used to select a representative sample from the three strata's of the population. According to the Universal Accreditation Board (2003), for a population of $n$ with $95 \%$ confidence interval and a margin of error of $+/-5 \%$, the appropriate sample size can be derived; the sample size so derived for this study is 358 households. Based on this and taking into account the possibility of non-response from some respondents when the data was collected, there was the option of taking some sample residential houses or incorporating data from the entire population. The target respondents were household heads who represented the 
selected households as decision makers in the homes.

\subsection{Research Instruments}

Structured questionnaires composed of closed ended items which were used to collect data. This was to ensure that the respondents were restricted to specific categories in their responses. Open ended questions were also used to further derive more information in relation to the answers made in the close ended questions. Responses would be ranked on a five-point Likert Scale to give an indication of the degree of the aspect being measured. The Likert Scale would be used as it is simple to construct, easy to read and complete and likely to produce highly reliable data. Key informants in the sector under research were also interviewed. An interview schedule was prepared and used during the interview. Those who were interviewed included the County Electrical Engineer from the Ministry of Public Works, the Commercial Manager Kenya Power, and the Director of Housing Municipal Council of Nakuru.

The questionnaire was pilot tested (pretested) with a representative sample of three categories, in Naivasha Town Council that have a similar characteristics as the estates under study in Nakuru Municipality residential houses. The results of the pilot study helped to identify necessary changes that were effected to improve the instrument prior to its administration.

\subsection{Data Analyses Techniques}

The filled up questionnaires were checked for completeness, consistency and clarity. The responses were coded by assigning a numerical value to each to make them quantitative that made it possible for the data to be entered in to the computer using the SPSS for Windows Version 19 for analysis. In order to establish the extent to which alternative energy is used among households, descriptive statistics of frequencies and percentages were used, further inferential statistics was employed. Correlations and chi square for hypothesis testing was used to summarize opinions of the respondents. Tables were generated to obtain a general view of the respondents' opinions on the influence of selected variables.

\section{Discussion of Results}

\subsection{Monthly Electricity Bills}

Respondents were requested to rate their monthly electrical bills in a 5-likert scale of very fair to very unfair. This indirect question was to aid in evaluating the respondents perception of their consumption visa vis the charges by KPLC. This in turn was to assist in inferring the respondents' satisfaction and acceptance of their consumption of electricity and in away bring out their conscious level of electricity consumption. The table 4 shows the response of the monthly bill rating by the occupants of which a majority of $38.0 \%$ said it is fair, $23.9 \%$ said it is unfair, $18.4 \%$ said it is very unfair, $12.8 \%$ said they were note sure while $6.9 \%$ said the bills were very fair. By inference therefore most respondents felt that they efficiently used electricity and that the charges were representative of their consumption.

Table 2. Respondent's Monthly Bills

\begin{tabular}{lll}
\hline Response & Frequency & Percent \\
\hline Bills & & \\
Very Fair & 21 & 6.9 \\
Fair & 116 & 38 \\
Note sure & 39 & 12.8 \\
Unfair & 73 & 23.9 \\
Very unfair & 56 & 18.4 \\
Agreement with previous bill & & \\
Strongly agree & 28 & 9.2 \\
Agree & 87 & 28.5 \\
Not sure & 63 & 20.7 \\
Disagree & 57 & 18.7 \\
Strongly disagree & 70 & 22.9 \\
Reason for above response & & \\
Indifference & 11 & 9.7 \\
Fair charges & 88 & 77.9 \\
Constant bills & 13 & 11.5 \\
\hline
\end{tabular}

\subsection{Respondents' Feelings on Previous Month'S Bill}

Households were asked to state whether they were in concurrence with their previous month's electricity bill. This was a follow question to the one discussed on rating of monthly bills. The aim of this question was to gauge consistency of the answer from the previous answer so that an objective decision could be arrived at. The response was as follows: $9.2 \%$ strongly agreed with the bill, $28.5 \%$ said they agreed, $20.7 \%$ were not sure, $18.7 \%$ said they disagreed and $22.9 \%$ said they strongly disagreed with the bill. The answers offered here do not tally with the previous question. The probable reason for that might be construed to mean that the respondents did not answer the previous question correctly. In the initial question as whether they agreed with this month's bill $44.9 \%$ said fair and very fair while the question of whether they agreed with the last month's bill attracted $37.7 \%$ rating of strongly agree and agree with last month's bill. Though the difference is not much at $7.2 \%$, it is the view of the researcher that respondents give little regard to the KPLC billing and their content. Probability that the of use of technical jargon in the electricity bills may pose a challenge for consumers to interrogate the bills in order to offer an objective response, such as the one required by the two questions above.

\subsection{Conservation of Electric Energy}

Respondents were asked whether they were aware of any method of conservation of electrical energy. This question was aimed at bringing out the awareness level among households on the methods of energy conservation. These findings show that a majority of respondents were aware of methods used in conservation of electrical energy in their houses whereby $55.1 \%$ of them said Yes while the $44.9 \%$ said No. 
Table 3. Methods of conservation of electric energy

\begin{tabular}{lll}
\hline Response & Frequency & Percent \\
\hline Yes & 168 & 55.1 \\
No. & 137 & 44.9 \\
Switching off lights & 91 & $29.8 \%$ \\
Energy saving bulbs & 69 & $22.6 \%$ \\
Alternative energy source & 74 & $24.3 \%$ \\
Appliances avoidance & 56 & $14 \%$ \\
Education on conservation & 5 & $1.6 \%$ \\
\hline
\end{tabular}

\subsection{Compliments to Electric Energy}

Knowledge of existence of other compliments to electricity energy was put to test. Respondents were asked whether they knew of any other compliment to electricity energy. A majority of $70.8 \%$ of the respondents believe that there are other forms of energy that can or are used in the household while $29.2 \%$ do not know of any. The respondents were asked to name any other compliment to electricity that they were aware of, $40 \%$ mentioned solar energy, $16.4 \%$ cited biogas, while $12.7 \%$ mentioned candles which can be categorized as biomass.

Table 4. Compliments to Electricity

\begin{tabular}{lll}
\hline Response & Frequency & Percent (\%) \\
\hline Knowledge on compliments & & \\
YES & 216 & 70.8 \\
NO & 89 & 29.2 \\
Type of source of energy & & \\
Solar & 122 & 40 \\
Candle & 39 & 12.7 \\
Charcoal & 17 & 5.6 \\
Geothermal & 20 & 6.6 \\
Biogas & 50 & 16.4 \\
Wood & 13 & 4.2 \\
Coal & 3 & 1 \\
Lamps & 30 & 9.8 \\
Wind & 9 & 3 \\
Water & 8 & 2.6 \\
Generators & 13 & 4.3 \\
LPG & 10 & 3.3 \\
Fuel & 11 & 3.6 \\
Lanterns & 8 & 2.6 \\
Others & 5 & 1.6 \\
\hline
\end{tabular}

Table 5. Solar energy Crosstab

\begin{tabular}{|c|c|c|c|c|c|c|c|}
\hline & & & Income & & & & \\
\hline & & & $0-10000$ & $10000-20000$ & $20000-50000$ & 50000 & Total \\
\hline & $\mathrm{Y}$ & Count & 11 & 9 & 12 & 2 & 34 \\
\hline Solar & $\mathrm{Y}$ & $\%$ within Income & $8.0 \%$ & $11.3 \%$ & $16.9 \%$ & $12.5 \%$ & $11.1 \%$ \\
\hline Solal & $\mathrm{N}$ & Count & 127 & 71 & 59 & 14 & 271 \\
\hline & $N$ & $\%$ within Income & $92.0 \%$ & $88.8 \%$ & $83.1 \%$ & $87.5 \%$ & $88.9 \%$ \\
\hline Total & & Count & 138 & 80 & 71 & 16 & 305 \\
\hline Total & & $\%$ within Income & $100.0 \%$ & $100.0 \%$ & $100.0 \%$ & $100.0 \%$ & $100.0 \%$ \\
\hline
\end{tabular}

Table 6. Chi-Square Tests

\begin{tabular}{lllc}
\hline & Value & df & Asymp. Sig. (2-sided) \\
\hline Pearson Chi-Square & $3.809^{\text {a }}$ & 3 & .283 \\
Likelihood Ratio & 3.661 & 3 & .301 \\
Linear-by-Linear Association & 2.964 & 1 & .085 \\
N of Valid Cases & 305 & & \\
\hline
\end{tabular}

\subsection{Income Level and Use of Alternative Energy}

Table 7. Fuel energy Crosstab

\begin{tabular}{|c|c|c|c|c|c|c|c|}
\hline & & & \multicolumn{4}{|l|}{ Income } & \multirow{2}{*}{ Total } \\
\hline & & & $0-10000$ & $10000-20000$ & $20000-50000$ & Over 50000 & \\
\hline \multirow{4}{*}{ Fuel } & \multirow{2}{*}{$\mathrm{Y}$} & Count & 87 & 49 & 38 & 10 & 184 \\
\hline & & $\%$ within Income & $63.0 \%$ & $61.3 \%$ & $53.5 \%$ & $62.5 \%$ & $60.3 \%$ \\
\hline & \multirow{2}{*}{$\mathrm{N}$} & Count & 51 & 31 & 33 & 6 & 121 \\
\hline & & $\%$ within Income & $37.0 \%$ & $38.8 \%$ & $46.5 \%$ & $37.5 \%$ & $39.7 \%$ \\
\hline Total & & Count & 138 & 80 & 71 & 16 & 305 \\
\hline
\end{tabular}

Table 8. Chi-Square Tests

\begin{tabular}{llll}
\hline & Value & df & Asymp. Sig. (2-sided) \\
\hline Pearson Chi-Square & $1.860^{\mathrm{a}}$ & 3 & .602 \\
Likelihood Ratio & 1.842 & 3 & .606 \\
Linear-by-Linear Association & .963 & 1 & .327 \\
N of Valid Cases & 305 & & \\
\hline
\end{tabular}

The Chi - Square Test for the solar energy were tested against the level of income, the result was a p-value of 0.602 . Therefore $p>0.05$ thus we reject the alternative hypothesis and fail to Reject the null hypothesis. 
Table 9. Charcoal energy (Biomass) Crosstab

\begin{tabular}{|c|c|c|c|c|c|c|c|}
\hline & & & Income & & & & \\
\hline & & & 0-10000 & $10000-20000$ & $20000-50000$ & Over 50000 & Total \\
\hline \multirow{4}{*}{ Charcoal } & \multirow[b]{2}{*}{ Y } & Count & 113 & 68 & 51 & 13 & 245 \\
\hline & & $\%$ within Income & $81.9 \%$ & $85.0 \%$ & $71.8 \%$ & $81.3 \%$ & $80.3 \%$ \\
\hline & \multirow{2}{*}{$\mathrm{N}$} & Count & 25 & 12 & 20 & 3 & 60 \\
\hline & & $\%$ within Income & $18.1 \%$ & $15.0 \%$ & $28.2 \%$ & $18.8 \%$ & $19.7 \%$ \\
\hline \multirow{2}{*}{ Total } & & Count & 138 & 80 & 71 & 16 & 305 \\
\hline & & $\%$ within Income & $100.0 \%$ & $100.0 \%$ & $100.0 \%$ & $100.0 \%$ & $100.0 \%$ \\
\hline
\end{tabular}

Table 10. Charcoal and Income Chi-Square Tests

\begin{tabular}{llll}
\hline & Value & df & Asymp. Sig. (2-sided) \\
\hline Pearson Chi-Square & $4.569^{\mathrm{a}}$ & 3 & .206 \\
Likelihood Ratio & 4.363 & 3 & .225 \\
Linear-by-Linear Association & 1.458 & 1 & .227 \\
N of Valid Cases & 305 & & \\
\hline
\end{tabular}

The Chi - Square Test for the solar energy were tested against the level of income, the result was a p-value of 0.206 . Therefore $p>0.05$ thus we reject the alternative hypothesis and fail to reject the null hypothesis.

Table 11. LPG Crosstab

\begin{tabular}{|c|c|c|c|c|c|c|c|}
\hline & & & \multicolumn{4}{|l|}{ Income } & \multirow{2}{*}{ Total } \\
\hline & & & $0-10000$ & $10000-20000$ & $20000-50000$ & Over 50000 & \\
\hline \multirow{4}{*}{ LPG } & \multirow{2}{*}{$\mathrm{Y}$} & Count & 49 & 40 & 52 & 13 & 154 \\
\hline & & $\%$ within Income & $35.5 \%$ & $50.0 \%$ & $73.2 \%$ & $81.3 \%$ & $50.5 \%$ \\
\hline & \multirow{2}{*}{$\mathrm{N}$} & Count & 89 & 40 & 19 & 3 & 151 \\
\hline & & $\%$ within Income & $64.5 \%$ & $50.0 \%$ & $26.8 \%$ & $18.8 \%$ & $49.5 \%$ \\
\hline \multirow{2}{*}{ Total } & & Count & 138 & 80 & 71 & 16 & 305 \\
\hline & & $\%$ within Income & $100.0 \%$ & $100.0 \%$ & $100.0 \%$ & $100.0 \%$ & $100.0 \%$ \\
\hline
\end{tabular}

Table 12. $L P G$ and Income Chi-Square Tests

\begin{tabular}{llll}
\hline & Value & Df & Asymp. Sig. (2-sided) \\
\hline Pearson Chi-Square & $33.156^{\mathrm{a}}$ & 3 & .000 \\
Likelihood Ratio & 34.415 & 3 & .000 \\
Linear-by-Linear Association & 32.290 & 1 & .000 \\
N of Valid Cases & 305 & & \\
\hline
\end{tabular}

The Chi - Square Test for the LPG was carried out against the level of income, the result was a p-value of 0.001 . Therefore $\mathrm{p}<0.05$ thus we accept the alternative hypothesis and reject the null hypothesis. Thus the hypothesis can be restated that- There is a significant relationship between level of income and usage of LPG as a compliment/alternative energy source to electricity.

\section{Conclusions}

The study has concludes that the usage of electricity among households of the Municipal Council of Nakuru is influenced by the economic status of households. However, this influence is less or minimal. Affordability of compliments such as LPG allows for flexibility in choosing the type of energy to use and thus to an extent economic status of a family influences efficient usage of electricity. Availability and affordability of compliments to electric energy influences efficient usage of electricity. This is because if the compliment (s) is affordable then a wider population may be compelled to use alternative energy to electricity thus leaving spare capacity that may be utilized in other sectors preferably manufacturing sector.

The recommendations derived from the study are three tier; recommendation to the consumers; to the Government and
Kenya Power and Lighting Company and the Municipal Council of Nakuru and Other developers. It is recommended that the Municipal Council of Nakuru and other future housing developers consider installation of solar panels as an integral part of the buildings. The cost of installation of a hot water cylinder as has been the practice may mitigate the cost of installation of solar panels. This will save the country a substantial quantity of energy that goes to waste. Further the council and developers should install fittings that conform to appliances that are energy saving, such as having screw type of lamp holders that can only work with energy saving bulbs and not tungsten or incandescent bulbs.

The Government and the KPLC should step up and enhance sensitization of the public on the need to conserve electricity and or to use electricity efficiently. KPLC has had demonstration centres that offer advice to the public on best practices, however the company has not popularized these centres, it is recommended that they publicize these centres for the public to benefit from what they teach. The Government has undertaken and continues to undertake major infrastructural development for power generation it is recommended that it takes with the same zeal and effort training and sensitization of its populace on best practices as regards electricity usage. Similar studies may be carried out but for owned residential houses where the household has control over the kind of installation he would want to install.

\section{References}

[1] Allingham, M. (2002). Choice Theory: A Very Short Introduction, Oxford. 
[2] Balla, P. (2006) National Study on Small Hydropower Development: Status and Potential of Small Hydropower Development in the Tea Industry in Kenya, unpublished report, Nairobi and Mombasa, UNEP/GEF and East African Tea Trade Association (EATTA)'

[3] Basa, G. S. \& Princess J. T. M. (2009). Energy Conservation Practices in Selected Households in Ald.

[4] Brandon, G. R. (1993). Factors Affecting the Relationship Between Expressions of Environmental Concern. Climate Africa Network

[5] Cook, S. \& Berenberg, J. (1981). Approaches to encouraging conservation behaviour: a review and conceptual framework. Journal of Social Issues 73]107.

[6] Daraga, A. (2005). Occasional Paper 26: Renewable in Kenya's Electricity Industry: A Review of Geothermal and Cogeneration Technologies, Nairobi. African Energy Policy Research Network

[7] Fishbein, M. \& Ajzen, I. (1975). Belief, Attitude, Intention and Behaviour. Reading, MA: Addison-Wesley.

[8] Gallup, G. \& Newport, F. (1990). The effect of goal-setting and daily electronic feedback on in-home energy use. Journal of Consumer Research 98]105.

[9] Goett, A.A. and Hudson, K., (2000). Customers' choice among retail energy suppliers: The Willingness-To-pay for service attributes. Energy Journal, 21 (4), 1-28.

[10] GOK (2004b). Sessional Paper No.4 of 2004 on Energy, Nairobi, Government of Kenya (GOK)

[11] GOK (2006) Code of Regulations (Revised), Director of Personnel Management.

[12] Gwendolyn \& Allan, L. (1999) Reducing Household Energy Consumption: A Qualitative and Quantitative Field Study. Journal of Environmental Psychology ,pp 83

[13] HMSO. Ester, P. (1985). Consumer Behaviour and Energy Conservation. Solar Energy Research Institute, US Department of Energy.

[14] Horn of Africa (2000), Nairobi, Energy, Environment and Development Network for Africa (AFREPREN/FWD).

[15] Howden-Chapman, P. (2009) Warm Homes: Drivers of the Demand for Heating in the Residential Sector in New Zealand. Energy policy, Vol. 37, No 9 pp 3387-99

[16] Hutton, R. B., Mauser, G. A., Filiatrault, P. \& Ahtola, O. T. (1986). Effects of cost related feedback on consumer

[17] Jadresic, A., (2000). Promoting private investment in rural electrification- The case of Chile. Private Sector and Infrastructure Network Note number 214. World Bank, Washington, DC

[18] Joerges, B. \& Muller, H. (1983). Energy conservation programs for consumers: a comparative analysis of policy conflicts and program results in eight western countries. Journal of Economic Psychology, (1)35.

[19] Karekezi and K, (2005). Sustainable Energy in Africa: Cogeneration and Geothermal in the East and Horn of Africa - Status and Prospects, Nairobi, AFREPREN/FWD

[20] Karekezi, S. (2002). 'Renewables in Africa - Meeting the
Energy Needs of the Poor', Energy Policy, Vol. 30 Nos. 11-12. Special Issue - Africa: Improving Modern Energy Service for the Poor, Oxford, Elsevier Ltd

[21] Kasulis, J. J., Huettner, D. A. \& Dikeman, N.J. (1981).The feasibility of changing electricity consumption patterns. Journal of Consumer Research 279-290.

[22] Kenya Institute for Public Policy Research and Analysis (2010) A comprehensive Study and Analysis on Energy Consumption Patterns in Kenya. (KIPPRA)

[23] Kenya Integrated Household Budget Survey (KIHBS), (2007). Volume 1 basic report, 2005/06. Ministry of Planning and National Development (MoPND), Nairobi, Kenya

[24] Kenya Pipeline Company Ltd (2006b). A Report on Current and Projected Consumption and Demand of Petroleum Products in the Great Lakes Region. 28th April 2006. KPC: Nairobi.

[25] Kluger, A. \& DeNisi, A. (1996). The effects of feedback interventions on performance: a historical review, a meta-analysis, and a preliminary feedback intervention theory. Psychological Bulletin, 254-284.

[26] KPLC (2006).Annual Report, 2006, Nairobi, Kenya Power and Lighting Company (KPLC)

[27] Lea, S., Tarpy, R. \& Webley, P. (1987). The Individual In The Economy. Cambridge: C.U.P.

[28] Lewis, A., Webley, P. \& Furnham, A. 1995.. The New Economic Mind: the social psychology of economic behaviour. LondonrNew York: Harvesterr Wheatsheaf.

[29] Longo, A., Markandya, A., and Petrucci, M., 2008. The internalization of externalities in the production of electricity: Willingness to pay for the attributes of a policy for renewable energy. Ecological Economics, 67(1), 140-152

[30] McDougall, G., Claxton, J., Ritchie, B. \& Anderson, C. (1981). Consumer energy research: a review. Journal of Consumer Research 343-354.

[31] MoE, (2002): Study on Kenya's Eenrgy Demand, Supply and Policy Strategy for Households, Small Scale Industries and Service Establishments, Nairobi, Ministry of Energy (MoE)

[32] Nandi, S. \& Bose, R.K. (2010). The Imperative of Efficient Energy Use in Cities: Analytical Approaches and Good Practices in Bose R.K. (ed.) Energy Efficient Cities: Assessment Tools and Benchmarking Practices, pp 1-19, The World bank, Washington D.C

[33] Orodho,J (2005). Elements of Education and Social Science Research Methods, Masola Publishers Nairobi pp145

[34] O'Sullivan, K. and Barnes, D.F. (2006). Energy policies and multitopic household surveys: Guidelines for questionnaire design in living standards measurement studies. Paper No. 17. Energy and Mining Sector Board Discussion Paper, ESMAP, Washington, DC.

[35] Otegbulu, Austin C. (2010). Energy Efficient Practice: A Focus On Residential Households, Department of Estate Management; University of Lagos

[36] Otivar. (2009). Energy Conservation Practices in Selected Households in Five Barangays in Legazpi City. Unpublished Undergraduate Thesis, College of Business, Economics and Management. 
[37] Pallak, M., Cook, D. \& Sullivan, J. (1980). Commitment and Energy Conservation. Inc. Bickman Ed.

[38] Rabah, K.V.O, (2005). Integrated solar energy systems forrural electrification. Renewable Energy, 30 (1), 23-42.

[39] Republic of Kenya (2001). Study on Kenya's Energy Demand, supply and Policy. Strategy for Households, Small-scale Industries and Service, Establishments, Government Printer.

[40] Ritchie, B., McDougall, G. \& Claxton, J. (1981). Complexities of household energy consumption and conservation.

[41] Muma, B. O., Nyaoga, R. B., Matwere, R. B. and Onyango J. O. (2014). Green Supply Chain Management and Economic Performance: A Review of Tea Processing Firms in Kericho and Bomet Counties, Kenya. International Journal of Science and Research, 3 (11), 2319-7064

[42] Roe, B., Teisl, M., Levy, A., and Russell, M., (2001). US consumers' willingness to pay for green electricity. Energy Policy, 29, 917-925.

[43] Sanghvi, A. and Barnes, D., (2001). Rural electrification: Lessons learned. World Bank Findings: Operational Quality and Knowledge Services, Africa Region Infrastructure 177. World Bank, Washington, DC.

[44] Van der Plas, R. J. and Hankins, M. (1998). Solar electricity in Africa: A reality.Energy Policy, 26, 295-305.

[45] Wamukonya, N., (2007). Solar home system electrification as a viable technology option for Africa's development, Energy Policy, 35, 6-14.

[46] Seligman, C., Kriss, M., Darley, J., Fazio, R. H., Beck, L. J. \& Pryor, J. B. (1979). Predicting summer energy consumption from home owners' attitudes. Journal of Applied Social Psychology, 70-90.

[47] Southwick, C.H, (1976). Ecology and the quality of our environment $2^{\text {nd }}$ edition. D. Van Nostrad Company 450 west $33^{\text {rd }}$ street, New York.

[48] Muma, B. O., Nyaoga, B. R., Matwere, B. R. and Nyambega, E. K. (2014). Green Supply Chain Management and Environmental Performance among Tea Processing Firms in Kericho County, Kenya. International Journal of Economics, Finance and Management Science 2(5) 270-276 